\title{
The new EU Succession Regulation in a nutshell
}

\author{
Angelika Fuchs ${ }^{1}$
}

Published online: 4 August 2015

(C) ERA 2015

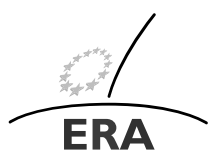

EUROPÄISCHE RECHTSAKADEMIE ACADEMY OF EUROPEAN LAW ACADEMIE DE DROIT EUROPEEN ACCADEMIA DI DIRITTO EUROPEO TRIER - TREVES - TREVIRI

\section{Introduction}

Multinational families or individuals with assets in different states, for example a bank account or a holiday home abroad, have been faced with conflicting (private international) laws which have led to difficulties, delays and uncertainties both during the planning stage of a succession and following a death. Facing this situation, the new EU Succession Regulation (EU) No 650/2012 ${ }^{1}$ which is applicable since $17 \mathrm{Au}-$ gust 2015 aims to ameliorate and simplify international inheritance rules. However, due to various uncertainties it consequently provides for new challenges in crossborder estate planning. ${ }^{2}$

\section{Main features}

\subsection{Synchronisation of ius and forum}

Both the provisions on international jurisdiction and the applicable law refer to the law of the state in which the deceased had his habitual residence at the time of death

\footnotetext{
${ }^{1}$ Regulation (EU) No 650/2012 of the European Parliament and of the Council of 4 July 2012 on jurisdiction, applicable law, recognition and enforcement of decisions and acceptance and enforcement of authentic instruments in matters of succession and on the creation of a European Certificate of Succession, OJ L 201/107 of 27 July 2012.

${ }^{2}$ Lively discussions on this issue took place at the ERA Conference "The new regime for planning crossborder successions" on 11-12 June 2015 among more than 100 participants from 23 states.
}

$\bowtie$ Dr. A. Fuchs, LL.M. (London), Head of Section European Private Law afuchs@era.int

1 Academy of European Law (ERA), Metzer Allee 4, 54295 Trier, Germany 
(Arts 4 and 21). These provisions reflect the endeavour to align forum and ius, i.e. the authority dealing with succession will, as a general rule, be applying its own law ("Gleichlauf"; cf. Recital 27).

\subsection{Main connecting factor: habitual residence of the deceased}

The main connecting factor, the habitual residence of the deceased at the time of death, was unknown to the laws of most of the Member States before the entry into force of the Succession Regulation. They rather applied the law of the state of nationality or domicile or the place of the asset. Like other civil justice instruments, the Regulation contains no definition of the "habitual residence" but implies that an autonomous interpretation should be used, to which the lengthy Recitals 23 and 24 provide some guidance. The authority "should make an overall assessment of the circumstances of the life (...) taking into account all relevant factual elements (...)"; eventually the habitual residence thus determined "should reveal a close and stable connection with the State concerned (...)." Thus, the habitual residence under this Regulation has to be particularly stable; it might even be argued that it has to be more stable than under the Family Law Regulations like the Brussels $\mathrm{IIa}^{3}$ and the Rome III $^{4}$ Regulations. If this were the case, the jurisprudence of the Court of Justice of the European Union on the interpretation of the habitual residence under Brussels II which mainly concerns minors could not simply be transferred, but would have to be interpreted for the purposes of the Succession Regulation. However, in order to keep a high level of legal certainty and to consequently allow citizens to avail themselves of the benefits offered by the internal market, it seems preferable to apply a uniform interpretation of "habitual residence" to all Regulations in the area of judicial cooperation in civil matters. 5

\subsection{Unitary approach}

The Regulation follows the idea of a single scheme which allows the succession in most cases to be subjected to a single law which will then govern the succession as a whole and does not divide movable and immovable property. If, for instance, a person chooses the law applicable to the succession, this law will have to govern the succession as a whole (Art 22); a partial choice of law is not permitted.

But please note that in relation to third states, a scission system might arise and will create several bodies of assets, ${ }^{6}$ each one subject to a different law which potentially determines heirs differently.

\footnotetext{
${ }^{3}$ Council Regulation (EC) No 2201/2003 of 27 November 2003 concerning jurisdiction and the recognition and enforcement of judgments in matrimonial matters and the matters of parental responsibility, repealing Regulation (EC) No 1347/2000, OJ L 338/1 of 23 December 2003.

${ }^{4}$ Council Regulation (EU) No 1259/2010 of 20 December 2010 implementing enhanced cooperation in the area of the law applicable to divorce and legal separation, OJ 343/10 of 29 December 2010.

${ }^{5}$ Palandt-Thorn [5], Art 21 EuErbVO, no 5.

${ }^{6}$ See below 3.4. and note 12 .
} 


\section{Contents}

\subsection{Scope of application}

As with other civil judicial cooperation instruments, this Regulation does not apply to Denmark; the UK and Ireland have decided not to participate. All other 25 EU Member States are bound by it.

The scope of the Succession Regulation is broad: it covers jurisdiction, applicable law, recognition and enforcement of decisions as well as acceptance and enforcement of authentic instruments and the creation of a European Certificate of Succession (ECS). The Succession Regulation applies to successions to the estates of deceased persons and covers all forms of transfer of assets, rights and obligations by reason of death, both voluntary transfer and intestate succession (cf. Art 3 para 1 (a)). It does not apply to revenue, customs or administrative matters (Art 1 para 1) and other issues listed in para 2, like matrimonial property regimes or property rights created or transferred otherwise than by succession. Moreover, it should be noted that the Regulation does not harmonise the succession laws of the Member States and it does not address tax issues. ${ }^{7}$

To sum up, people who live in one of these 25 EU Member States, those who own property there or who are moving to/from one of these states, should take the EU Succession Regulation into consideration when planning their estate.

\subsection{Jurisdiction and choice of court}

The courts of the Member State in which the deceased had his/her habitual residence at the time of death will have (general) jurisdiction to rule on the succession as whole (Art 4). This rule comes with a number of exceptions, especially in cases of choice of law, choice of court and appearance by parties in the proceedings who have not exercised a choice of court (cf. Arts 5-9). A "forum non conveniens" provision like in Art 15 Brussels IIa Regulation which allows a transfer of jurisdiction is not included in the Succession Regulation.

Where the deceased has his/her habitual residence in a third state, the courts of a Member State in which assets of the estate are located will have (subsidiary) jurisdiction (Art 10). If the courts have jurisdiction to rule on the succession as a whole (para 1) or only on the assets in this State (para 2) depends on further conditions.

\subsection{Applicable law and choice of law}

As has been mentioned, the law applicable to the succession is usually the law of the state - not Member State - in which the deceased had his/her habitual residence at the time of death (Art 21). Only by way of exception, a manifestly closer connection of the deceased to another state will be taken into account (Art 21 para 2); in this specific case the competent court has to apply a foreign law. The applicable law governs the succession from the opening of the succession to the distribution of the estate, including liability for the debts.

${ }^{7}$ Cf. on this issue: Weber-Frisch/Duquennois-Djoua [7]. 
Chap. III on applicable law also includes rules on the validity of dispositions upon death namely a will, a joint will ${ }^{8}$ or an agreement as to succession, in particular provisions on the admissibility, the formal and the substantive validity of such a disposition (Arts 24-27).

To a limited degree choice of law is accepted: a person may choose the law of the state whose nationality s/he possesses (at the time of making the choice or at the time of death) to govern the succession as a whole (Art 22). Where the person has more than one nationality, the law of the state of any of the nationalities can be chosen (para 2). In case the law chosen is the law of a Member State the "parties concerned" may agree that the courts of that state have exclusive jurisdiction to rule on any succession matter (Art 5) in order to assure the alignment of ius and forum; who could fall under the "parties concerned" is however not defined.

\subsection{Relation to third states}

Unfortunately the Regulation does not contain a definition of what a third state is. Therefore, a discussion has been raised regarding the UK, Ireland and Denmark, which are EU Member States but not bound by this Regulation. Are they simply third states like any other state external to the EU or do they form a third category, separate from participating Member States and third states, i.e. a category of noncompliant Member States? ${ }^{9}$ The dominant view at least on the continent considers these three countries simply as third states.

Any law specified by this Regulation shall be applied whether or not it is the law of a Member State (so-called universal application, Art 20). A court of a Member State has to apply the law of a third state in case of subsidiary jurisdiction (see above, Art 10) when the deceased has his or her habitual residence not in a Member State. Furthermore, the "forum legis" does not apply in the case that a third state national chooses the law of his or her state.

While the so-called renvoi is excluded in the Rome $\mathrm{I}^{10}$ and Rome $\mathrm{II}^{11}$ Regulations, the situation is different under the Succession Regulation: renvoi was abolished among the participating Member States, but the application of the law of any third state is meant to cover the rules of law including its conflict of laws rules insofar as those rules constitute a renvoi to either the law of a Member State or the law of another third state which would apply its own law (Art 34). Should this legal system determine the applicable law dependent upon the nature of the assets - the distinction between movables and immovables is for instance upheld in England, Scotland and

\footnotetext{
${ }^{8}$ Whether joint wills fall under dispositions of property upon death (Art 24) or under agreements as to succession (Art 25) is extensively debated in Germany: Palandt-Thorn [5], Art. 25 EuErbVO, no 3 with further references.

${ }^{9}$ See Crawford/Carruthers [1], p. 855.

${ }^{10}$ Regulation (EC) No 593/2008 of the European Parliament and of the Council of 17 June 2008 on the law applicable to contractual obligations (Rome I), OJ L 177/6 of 4 July 2008: Art 20.

${ }^{11}$ Regulation (EC) No 864/2007 of the European Parliament and of the Council of 11 July 2007 on the law applicable to non-contractual obligations (Rome II), OJ L 199/40 of 31 July 2007: Art 24.
} 
Wales $^{12}$ - a scission would become unavoidable and would lead to practical difficulties in the application of the Regulation.

\subsection{Recognition and enforcement}

The Succession Regulation lays down rules relating to the recognition, enforceability and enforcement of decisions, irrespective of whether such decisions were issued in a contentious or non-contentious way. Inspired by the Brussels I Regulation, the general principle is the ex lege recognition of decisions given in the Member States (Art 39). There are only a few grounds of non-recognition listed (Art 40) and a review as to substance is excluded (Art 41). Moreover, the Regulation contains provisions on the "acceptance" of authentic instruments and their enforceability (Arts 59,60) as well as the enforceability of court settlements (Art 61).

\subsection{European Certificate of Succession}

In order to settle the cross-border succession in a certain, speedy and less costly manner, heirs, legatees, executors of the will or administrators of the estate can demonstrate their status by showing a uniform certificate, the so-called European Certificate of Succession (ESC), which forms the main innovative element of this Regulation. ${ }^{13}$ The use of the ESC is voluntary and optional; the use of other (internal) instruments thus remains possible. Details regarding the application of the ECS, and the issue, contents and effects thereof are provided for in Chap. VI. ${ }^{14}$ The application forms have already been established and published; ${ }^{15}$ printable dynamic forms will soon be available on the E-Justice Portal. Eventually, the European Commission will launch a feasibility study on the registration of electronic ECS (e-ECS) and the interconnection of national registers of wills and e-ESC.

\section{Concluding remarks}

With more than 80 recitals, many of them of great length and considerable detail, the EU Succession Regulation forms a major piece of legislation; insiders described it as having been one of the most difficult dossiers in the area of judicial cooperation in civil matters ever to be negotiated in Brussels. ${ }^{16}$ In spite of the large degree

\footnotetext{
${ }^{12}$ Some examples in Crawford/Carruthers [1], p. 857-872. On the effects between EU Member States and Switzerland: Weiss/Bigler [8].

${ }^{13}$ Dutta [3], p. 14: "Quantensprung".

${ }^{14}$ Hertel [4].

${ }^{15}$ Commission implementing Regulation (EU) No 1329/2014 of 9 December 2014 establishing the Forms referred to in Regulation (EU) No 650/2012 of the European Parliament and of the Council on jurisdiction, applicable law, recognition and enforcement of decisions and acceptance and enforcement of authentic instruments in matters of succession and on the creation of a European Certificate of Succession, OJ L 359/30 of 16 December 2014. - Dorsel/Schall [2], p. 47 criticise the forms as unnecessarily bureaucratic and evitably complex.

${ }^{16}$ Wagner [6], p. 1334.
} 
of diligence and attention to detail, some questions of central importance still remain open. Some examples may help to illustrate this: the key notion of "habitual residence" finds its explanation in Recital 23, but it is still unclear whether an autonomous European concept of "habitual residence" exists, or whether this is to be defined individually in the context of each Regulation.

Moreover, the line drawn between the law applicable to the succession on the one hand and property law (lex rei sitae) on the other within the Succession Regulation raises difficult problems. The same is true for the interrelationship of the law of succession and matrimonial property law or company law. In spite of the long and detailed recitals which aim to clarify the intricacies of these interconnections, difficulties in characterisation and possibly adaptation will certainly remain in legal practice. Finally, scissions which should have been avoided in the context of the Regulation will arise in relation to non-Member States.

In the light of the above, drafting choice of law and choice of court clauses will become highly relevant in the daily practice of lawyers and notaries who will need to become fully informed not only about the EU Succession Regulation but also regarding the relevant foreign laws in the field of succession including - depending on the case-aspects of property, matrimonial property or company law in order to give comprehensive advice to their clients.

\section{References}

1. Crawford, E.B., Carruthers, J.M.: Speculation on the Operation of Succession Regulation 650/2012: Tales of the Unexpected. European Review of Private Law 2014, 847-878

2. Dorsel, C., Schall, C.: Die Umsetzung der ErbVO durch die Europäische Kommission - Ein erster Überblick unter besonderer Berücksichtigung des Europäischen Nachlasszeugnisses, GPR 2015, 3648

3. Dutta, A.: Das neue internationale Erbrecht der Europäischen Union - Eine erste Lektüre der Erbrechtsverordnung, FamRZ 2013, 4-15

4. Hertel, C.: European Certificate of Succession - content, issue and effects, ERA Forum 2014, 393-407

5. Palandt: Bürgerliches Gesetzbuch: BGB, Munich, C.H. Beck, 74. ed. 2015

6. Wagner, R.: Aktuelle Entwicklungen in der justiziellen Zusammenarbeit in Zivilsachen, NJW 2012, 1333-1338

7. Weber-Frisch, N., Duquennois-Djoua, R.: Domestic inheritance tax rules in EU Member States regarding cross-border successions. ERA Forum 2014, 409-424

8. Weiss, K.M., Bigler, M.: Die EU-Erbrechtsverordnung - Neue Herausforderungen für die internationale Nachlassplanung aus Schweizer Sicht, successio 2/14, 163-193 